\section{Congenital Zika virus syndrome}

Síndrome da infecção congênita pelo vírus Zika Síndrome de la infección congénita del virus Zika

Viroj Wiwanitki 1

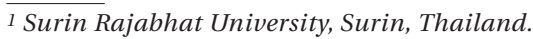

Correspondence

V. Wiwanitki

Surin Rajabhat University, Surin, Thailand.

wviroj@yahoo.com

doi:10.1590/0102-311X00133115

Dear Editors,

The recent paper on congenital Zika virus syndrome is very interesting 1 . Indeed, congenital Zika virus infection has been proven and has become a major global concern. The teratogenic effect of the virus can cause severe neurological problems for the fetus in utero if the pregnant mother becomes infected. There are nonetheless many new concerns about congenital Zika virus syndrome. First, not all infected pregnant women will end up giving birth to an abnormal infant. In previous outbreaks outside of South America, this problem never emerged: in areas with very high seropositive rates among local people in Southeast Asia, for example, there have never been reports of abnormal infants born to infected mothers 2. Furthermore, in affected cases, not all affected infants die. Some infants might manifest significant clinical problems ranging from a severe disability to just neurosensory hearing loss 3 . This implies that there might be various degrees of congenital Zika virus syndrome and that ethnic genetic background may have an important role to play. In cases of existing congenital Zika virus syndrome, there is a shortage of extensive research about other possible concurrent congenital infections that may cause the syndrome.
1. Eickmann SH, Carvalho MD, Ramos RC, Rocha MA, van der Linden V, Silva PF. Zika virus congenital syndrome. Cad Saúde Pública 2016; 32:e00047716.

2. San K, Rajadhan V. Seroprevalence of Zika virus in Cambodia: a preliminary report. Advance Laboratory Medicine International 2016; 6:37-40.

3. Miranda-Filho DB, Martelli CM, Ximenes RA, Araújo TV, Rocha MA, Ramos RC, et al. Initial description of the presumed congenital zika syndrome. Am J Public Health 2016; 106:598-600.

Submitted on $28 / \mathrm{Jul} / 2016$

Approved on 08/Sep/2016 